\title{
Type 1 Neurofibromatosis: Selective Expression of Extracellular Matrix Genes by Schwann Cells, Perineurial Cells, and Fibroblasts in Mixed Cultures
}

\author{
Sirkku Jaakkola, Juha Peltonen, Vincent Riccardi, “ Mon-Li Chu, and Jouni Uitto \\ Departments of Dermatology, and Biochemistry and Molecular Biology, Jefferson Medical College, and Section of Molecular \\ Dermatology, Jefferson Institute of Molecular Medicine, Thomas Jefferson University, Philadelphia, Pennsylvania 19107; and \\ *Neurofibromatosis Program, Baylor College of Medicine, Houston, Texas 77030
}

\begin{abstract}
Cutaneous neurofibromas, characteristic lesions of neurofibromatosis 1, are composed of an abundant extracellular matrix and nerve connective tissue-derived cell types: Schwann cells, perineurial cells, and fibroblasts. In this study, the extracellular matrix gene expression by these cells was examined under culture conditions that allowed them to be metabolically active and readily identifiable by morphologic and immunocytochemical criteria. Northern hybridizations demonstrated expression of genes for type I, III, IV, and VI collagens, as well as for fibronectin, laminin, and elastin. In situ hybridizations revealed that all three cell types expressed pro $\alpha_{1}(\mathrm{I})$, pro $\alpha_{2}(\mathrm{VI})$, and laminin B1 chain genes. However, fibroblasts did not contain ${ }^{35}$ S]cDNA-mRNA hybrids specific for type IV collagen, whereas both Schwann cells and perineurial cells expressed these genes. Perineurial cells and fibroblasts readily expressed the fibronectin gene whereas Schwann cells were essentially devoid of the corresponding mRNA. Perineurial cells also expressed the gene for laminin A chain. The results indicate that the extracellular matrix gene expression profiles of Schwann cells, perineurial cells, and fibroblasts are distinct: all three cell types are capable of expressing some of the genes for extracellular matrix components, such as type I and VI collagens, whereas Schwann cells and perineurial cells may have the primary role in synthesizing basement membrane zone components, type IV collagen and laminin. These observations potentially relate to the mechanisms of growth and development of human neurofibromas. The results attest to the applicability of the methodology utilized here to study other human tumors with mixed cell populations.
\end{abstract}

\section{Introduction}

Type 1 neurofibromatosis (von Recklinghausen's disease $[\mathrm{NF}-1]^{1}$ ) is a common neurocutaneous disease affecting $\sim 1$ out of 3,000-4,000 individuals (1). It is inherited in an autosomal dominant manner, and the genetic defect has been localized to chromosome $17(2,3)$. The most characteristic clinical

Address reprint requests to Dr. Uitto, Department of Dermatology, Thomas Jefferson University, 1020 Locust Street, Philadelphia, PA 19107.

Received for publication 11 January 1989 and in revised form 9 March 1989.

1. Abbreviation used in this paper: NF-1, type 1 neurofibromatosis (von Recklinghausen's disease).

J. Clin. Invest.

(c) The American Society for Clinical Investigation, Inc. 0021-9738/89/07/0253/09 \$2.00

Volume 84 , July 1989 , 253-261 features of NF-1 are the presence of cutaneous and subcutaneous neurofibromas, cafe-au-lait macules, and hamartomas of iris, the so-called Lisch nodules (4).

The cutaneous neurofibromas contain three major types of neural tissue-derived cells: Schwann cells, perineurial cells, and fibroblasts (5) which are embedded in an extensive connective tissue matrix. The extracellular matrix consists predominantly of collagen which comprises $\sim 50 \%$ of the dry weight of the tumors (6). Immunocytochemistry and electron microscopy have demonstrated the presence of at least five genetically distinct collagens, types I, III, IV, V, and VI, in the lesions (6-11). Previous studies have revealed that the levels of mRNA transcripts specific for type I procollagen are 10 times higher than the mRNA levels of type III or IV procollagens in RNA preparations isolated from neurofibroma tissue (12). In addition, fibronectin and basement membrane components, laminin and nidogen, have been identified in the matrix of neurofibromas $(5,7,10,13,14)$.

Although the composition of the extracellular matrix of neurofibromas has been investigated in considerable detail, the cellular origin of the matrix is not clear. Most tumors, once fully developed, appear to be biosynthetically stable, and only a few cells are active in expressing the extracellular matrix genes (5). In situ hybridizations have shown that in fully developed neurofibromas, $<10 \%$ of the cells actively express the pro $\alpha_{1}(\mathrm{I})$ collagen gene, whereas $<5 \%$ of the cells express the pro $\alpha_{1}$ (III) collagen gene (5). In this study, the contribution of Schwann cells, perineurial cells, and fibroblasts to the accumulation of the extracellular matrix in developing neurofibromas was investigated under culture conditions that allowed the cells to be metabolically active and also rendered them readily identifiable $(15,16)$.

\section{Methods}

Cell cultures. The primary cell cultures were established from cutaneous neurofibromas excised for cosmetic reasons from seven patients with clinically and histopathologically verified von Recklinghausen's neurofibromatosis (NF-1). The central part of each tumor was cut into $\sim 1-\mathrm{mm}^{3}$ pieces which were explanted onto plastic tissue culture flasks. Normal skin fibroblasts were similarly cultured from a skin sample of a 52-yr-old male undergoing surgery for cosmetic reasons. For in situ hybridization and immunofluorescence the cells were grown from tissue onto acetylated glass slides (16). The cells were grown for 4-5 wk in DME, supplemented with antibiotics (penicillin $\mathrm{G}, 100 \mathrm{U} / \mathrm{ml}$, and streptomycin sulphate, $50 \mu \mathrm{g} / \mathrm{ml}$ ), and $10 \%$ fetal calf serum. Before fixation of cells for in situ hybridization, the cells were fed for $6 \mathrm{~h}$ with fresh DME supplemented with $20 \%$ fetal calf serum.

Indirect immunofluorescence. For immunofluorescence staining, the cells grown on object glasses were fixed in $100 \%$ ethyl alcohol at $-20^{\circ} \mathrm{C}$ for $15 \mathrm{~min}$ or in fresh $4 \%$ paraformaldehyde. To prevent nonspecific antibody binding, the samples were incubated with $1 \%$ bovine

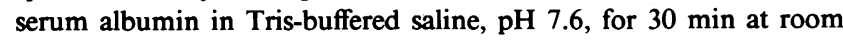


temperature. The cells were then incubated overnight at $4^{\circ} \mathrm{C}$ with one of the following primary antibodies: mouse IgG recognizing human type IV collagen epitopes (ICN ImmunoBiologicals, Lisle, IL); rabbit IgG to human plasma fibronectin, to human factor VIII-related antigen, or to cow S-100 protein (Accurate Chemical \& Scientific Corp., Westbury, NY); mouse monoclonal antibodies to human cytokeratin or to swine desmin (Dakopatts, Glostrup, Denmark); the latter antibody cross-reacts with human epitopes. The samples were washed with Tris-buffered saline for 60 min with five changes, and incubated with tetramethyl-rhodamine isothiocyanate-conjugated goat anti-mouse or anti-rabbit IgG (Cappel Laboratories, Cooper Biomedical, Inc., Malvern, PA).

RNA hybridization. Total RNA was isolated according to the single-step method described by Chomczynski and Sacchi (17). The RNA species were separated on $0.9 \%$ agarose gels under denaturing conditions and transferred to nitrocellulose filters (18). RNA was then immobilized by heating at $78^{\circ} \mathrm{C}$ under vacuum for $90 \mathrm{~min}$, and the filters were hybridized with one of the human sequence-specific cDNAs (see below), labeled with [ $\left.{ }^{32} \mathrm{P}\right] \mathrm{dCTP}$ by nick translation (19) to a specific activity of at least $1 \times 10^{8} \mathrm{cpm} / \mu \mathrm{g}$. For in situ hybridization, the cells grown on acetylated object glasses $(20,21)$ were permeabilized and fixed in $100 \%$ ethanol for $15 \mathrm{~min}$ at $-20^{\circ} \mathrm{C}$, and then in $4 \%$ paraformaldehyde at room temperature for $15 \mathrm{~min}$, after which the cultures were pretreated with $0.25 \%$ acetic anhydride in $0.1 \mathrm{M}$ triethanolamine to block nonspecific binding of the cDNAs $(20,21)$. The hybridization was performed for $16 \mathrm{~h}$ at $42^{\circ} \mathrm{C}$ in the presence of $50 \%$ formamide and $10 \%$ dextran sulphate, using cDNAs labeled with $\left[{ }^{35}\right.$ S]dATP by nick translation, as described earlier in detail $(5,21)$. After hybridizations, the samples were washed at $42^{\circ} \mathrm{C}$ to the final stringency of $30 \mathrm{mM}$ $\mathrm{NaCl}$ and $3 \mathrm{mM}$ sodium citrate, $\mathrm{pH} 6.8$, followed by dehydration in a graded series of ethanol $(5,21)$. The $\left[{ }^{35} \mathrm{~S}\right] \mathrm{cDNA}-\mathrm{mRNA}$ hybrids were detected by using NTB 3 emulsion (Eastman Kodak Co., Rochester, $\mathrm{NY}$ ) and by exposing the samples for $5-10 \mathrm{~d}$ at $4^{\circ} \mathrm{C}$. The samples were subsequently developed using D-19 developer (Eastman Kodak Co.) $\left(15^{\circ} \mathrm{C}, 120 \mathrm{~s}\right)$, stained with hematoxylin, and dehydrated with ethanol and xylene.

cDNA probes. The following human sequence-specific $\mathrm{cDNAs}$ were used for Northern and in situ hybridizations: for type I collagen, a 1.8-kb pro $\alpha_{1}(\mathrm{I})(\mathrm{Hf} 677)$ cDNA (22), and a 4.5-kb pro $\alpha_{2}$ (I) (Hp 2010) cDNA (23); for type III collagen, a 1.3-kb pro $\alpha_{1}$ (III) (Hf 934) cDNA (24); for type IV collagen, a 2.6-kb pro $\alpha_{1}(\mathrm{IV})$ (Ht-21) cDNA (25); for type VI collagen, three different cDNAs, 2.1 (p18), 1.5 (p8), and 1.5 (p24) $\mathrm{kb}$ in size, corresponding to pro $\alpha_{1}(\mathrm{VI})$, $\operatorname{pro} \alpha_{2}(\mathrm{VI})$, and $\operatorname{pro} \alpha_{3}(\mathrm{VI})$ chains, respectively (26); for fibronectin, a 1.3-kb (Hf 771) cDNA (27); for laminin, a $0.7-\mathrm{kb} 5^{\prime}$ EcoRI-PstI subfragment of 2.5-kb A chain ( $\lambda \mathrm{pA}-1) \mathrm{cDNA}, \mathrm{a} 2.4-\mathrm{kb} \mathrm{B} 1$ chain $(\lambda \mathrm{pB} 1-3) \mathrm{cDNA}$, and a $2.4-\mathrm{kb} \mathrm{B} 2$ chain ( $\lambda$ pB2-10) cDNA, respectively (28); for elastin, a 2.5-kb (cHE-3) cDNA (29).

\section{Results}

Identification of cells. Neurofibroma cells were cultured from seven separate tumors on plastic tissue culture flasks or on acetylated glass slides. The results presented below were consistently observed in all seven cases. The outgrowth of cells was examined first at light microscopic level. The presence of three different major cell types was noted in the initial outgrowth (Fig. 1). In several areas, a mixture of cells growing on a multilayer arrangement was noted (Fig. $1 \mathrm{~A}$ ). Immunocytochemical staining showed that the top layer of the cells was positive for S-100 protein (not shown), indicating that they were Schwann cells (30). These cells also stained positively with anti-type IV collagen antibody (Fig. $2 \mathrm{~A}$ ). The lower layer of these areas of cultures revealed heterogeneity in a manner suggesting the presence of fibroblasts and perineurial cells (see below). Both these cell types were negative for S-100 protein, but stained positively with anti-fibronectin antibody (15).

In some areas of primary outgrowth, the cells had a growth pattern characteristic of fibroblasts (Fig. $1 \mathrm{~B}$ ). These cells were negative for staining with anti-type IV collagen antibody (Fig.
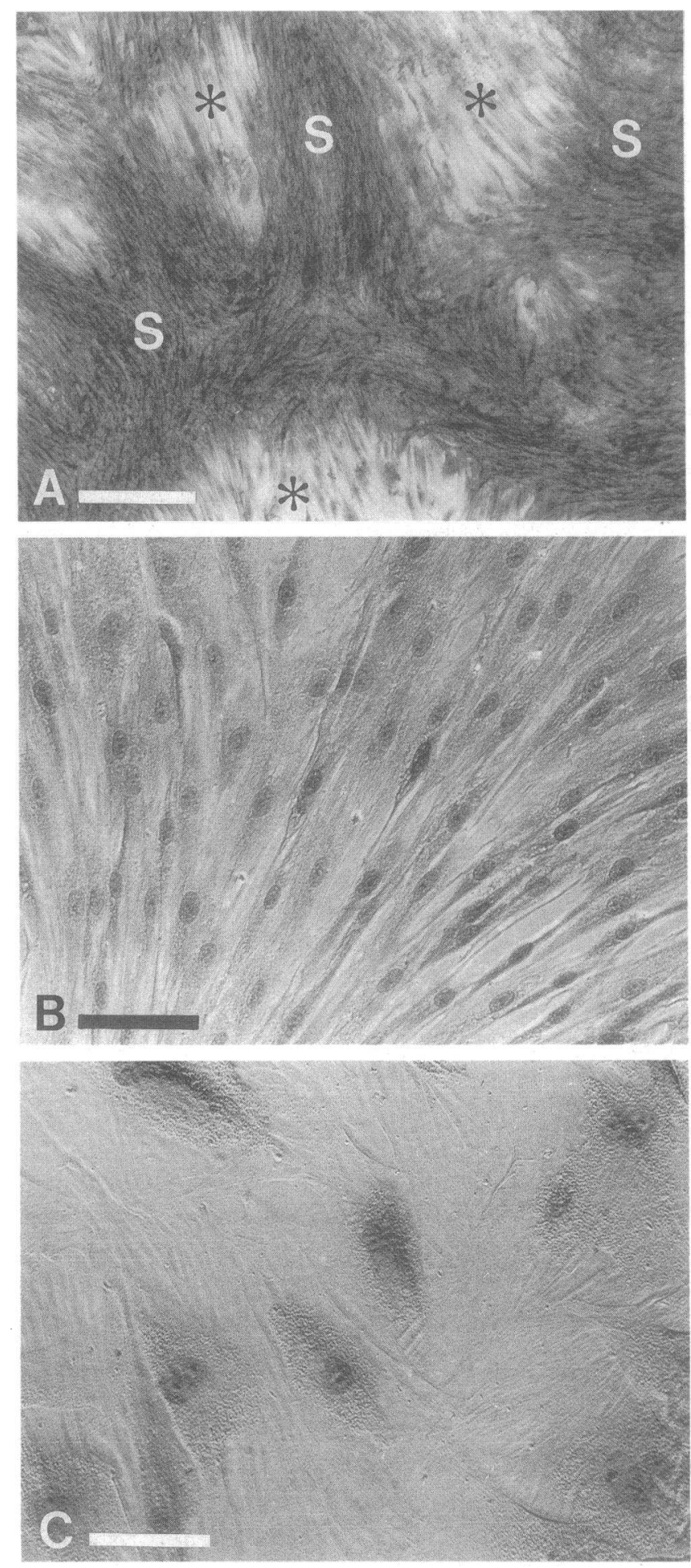

Figure 1. Primary neurofibroma cell culture. $(A)$ Arrays of Schwann cells $(S)$, visualized by toluidine blue grow on a layer of fibroblasts and perineurial cells $\left({ }^{*}\right)$. $(B$ and $C$ ) Phase-contrast micrographs of $(B)$ fibroblastic and $(C)$ perineurial cell outgrowths in localized areas of the culture. Bars, $500 \mu \mathrm{m}$ in $A ; 100 \mu \mathrm{m}$ in $B$ and $C$. 

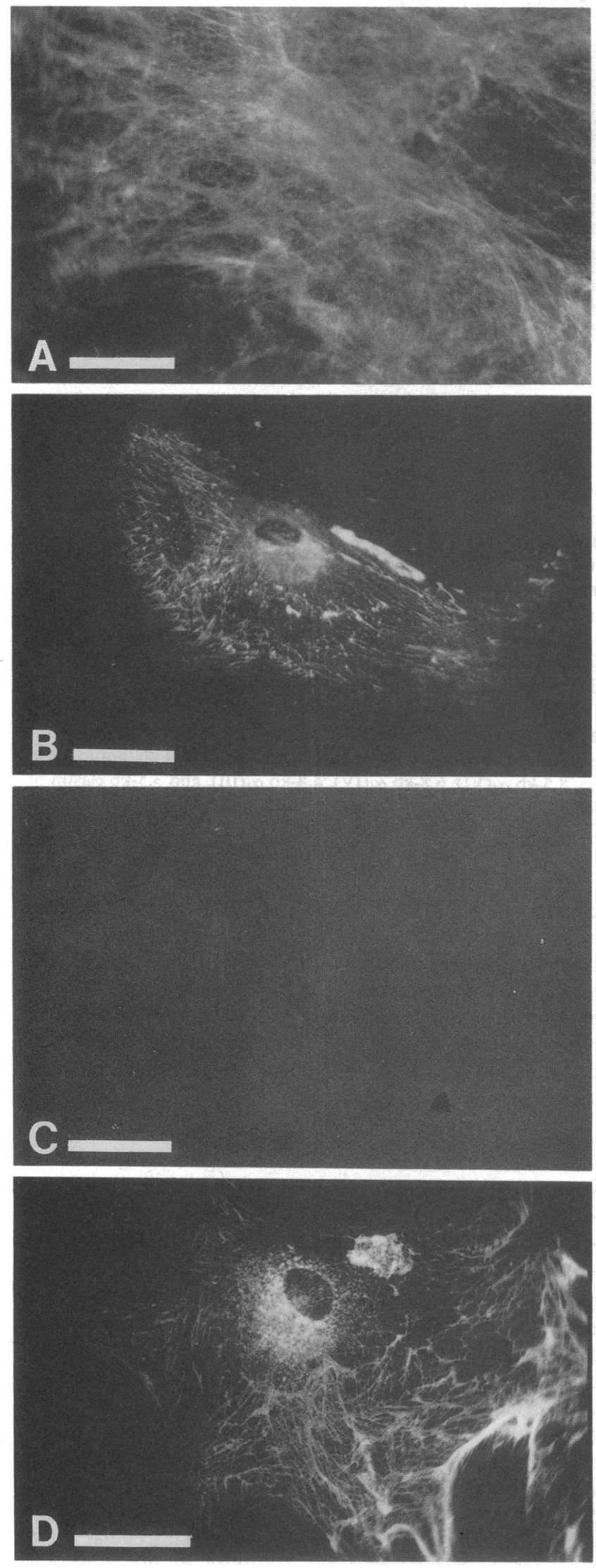

Figure 2. Indirect immunofluorescence staining of a neurofibroma primary cell culture with antibodies to $(A-C)$ type IV collagen or $(D)$ fibronectin. Positive reaction of type IV collagen is seen in associa-
$2 C)$. In areas containing predominantly cells with unusually large, squamous phenotype (Figs. $1 C$ and $2, B$ and $D$ ), a patchy cellular staining pattern with anti-type IV collagen antibody was noted (Fig. 2 B). On the basis of their characteristic morphology, and the presence of both fibronectin and type IV collagen epitopes, the latter cells were identified as perineurial cells $(15,16)$. None of the cells in the primary outgrowth were positive for factor VIII-related antigen, cytokeratin, or desmin, suggesting that they were not related to endothelial, epithelial or muscle cells $(31,32)$. Thus, the majority of cells in these mixed primary cell cultures appeared to represent Schwann cells, perineurial cells and fibroblasts $(15,16)$.

Matrix gene expression in primary cultures. To examine the matrix gene expression in primary cultures, Northern transfer analyses were first performed with several human sequence-specific cDNAs. These hybridizations clearly revealed the presence of characteristic polymorphic transcripts for type I, III, IV, and VI collagens, as well as for laminin B2 chain, fibronectin, and elastin (Fig. 3) (22-29). In addition, three out of seven neurofibromas studied revealed the presence of laminin A chain mRNA (Fig. $3 \mathrm{~B}$ ). These results indicated that at least one cell type within the primary culture was responsible for the expression of the corresponding matrix genes. A difference was noted, however, in the size of $\alpha_{3}(\mathrm{VI})$ collagen mRNAs. The mRNA transcript seen in primary neurofibroma cell cultures (Fig. $3 A$, lanes $b$ and $c$ ) was somewhat smaller than that in skin fibroblast cultures (lane $a$ ).

To identify the exact cell type(s) expressing each of the matrix genes in primary culture, in situ hybridizations were performed. The results, summarized in Table I, indicate clear differences in the profile of matrix gene expression between Schwann cells, perineurial cells, and fibroblasts. Although all three cell types expressed the $\alpha_{1}(\mathrm{I})$ and $\alpha_{2}(\mathrm{VI})$ collagen genes (Figs. 4 and 5), the mRNA transcripts corresponding to $\alpha_{1}$ (IV) collagen gene were clearly detectable only in perineurial and Schwann cells, but not in fibroblasts (Fig. 6). On the other hand, fibroblasts and perineurial cells expressed the fibronectin gene, whereas Schwann cells were essentially devoid of the corresponding transcripts, or expressed the fibronectin gene at a very low, undetectable level (Fig. 7). Whereas laminin B1 chain mRNAs could be demonstrated in all three different cell types, hybridization with a laminin A chain cDNA revealed detectable $\left[{ }^{35} \mathrm{~S}\right] \mathrm{cDNA}-\mathrm{mRNA}$ hybrids only in perineurial cells (Fig. 8). Thus, the latter observations attest to the uncoordinate and differential expression of the matrix genes, even when representing the separate subunit components of the same protein.

Matrix gene expression in subcultures. The expression of matrix genes was also examined by Northern hybridizations in the third passage of subculture. As judged by immunostaining for S-100 protein, these cultures were devoid of Schwann cells, which can not be propagated under the culture conditions used in this study. Consequently, the cultures were enriched either in perineurial cells or in fibroblasts, and contained these two cell types in varying proportions.

tion with $(A)$ the Schwann cell arrays and $(B)$ perineurial cells, whereas $(C)$ no staining reaction is seen in association with fibroblasts. $(D)$ Perineurial cells demonstrate the presence of fibronectin epitopes. Bar, $50 \mu \mathrm{m}$. 


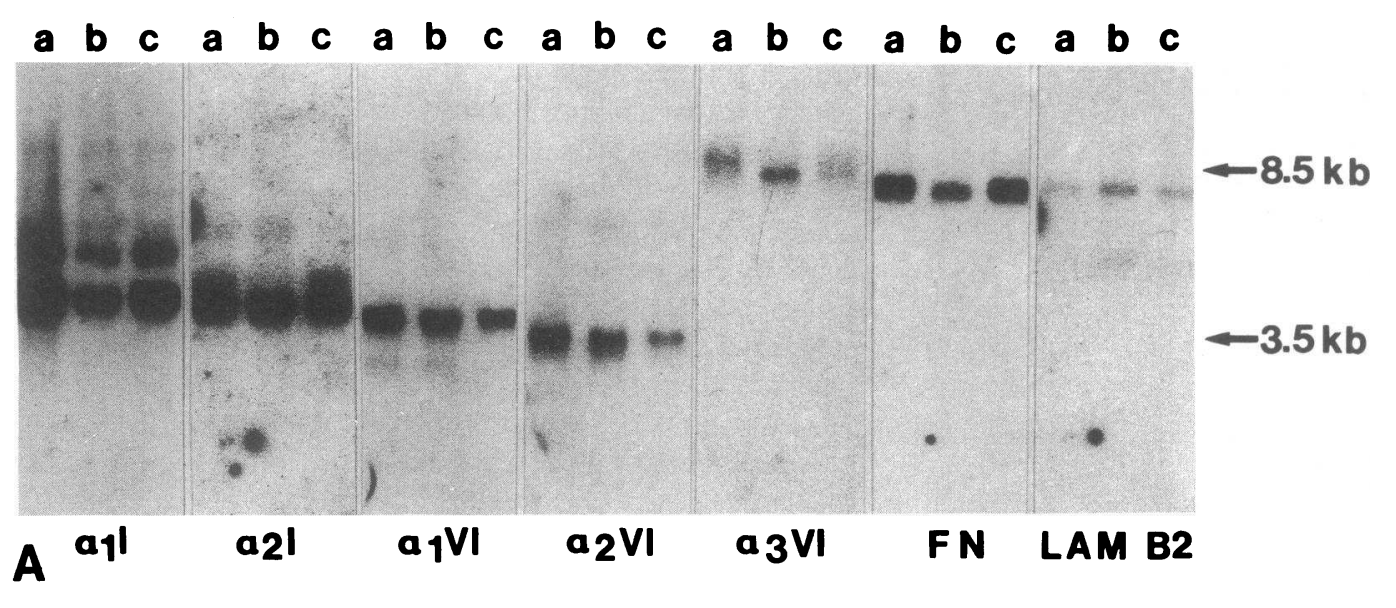

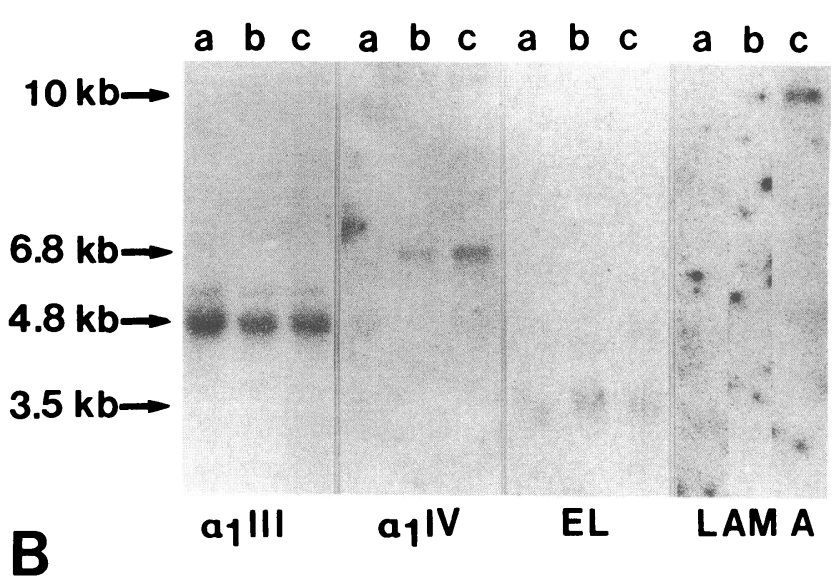

All mRNA transcripts that were detected in the primary cultures were also present in RNA preparations isolated from the cultured cells in the third passage (Fig. 3). However, the intensity of the hybridization signal between the primary and the third passage cultures appeared to diminish in the case of mRNA for type VI collagen polypeptides, although the intensity of fibronectin mRNA was somewhat increased. These changes are consistent with the depletion of the subcultures from Schwann cells which were shown to be particularly active

Table I. Extracellular Matrix Gene Expression Profiles of Schwann Cells, Perineurial Cells, and Fibroblasts Cultured from Human Neurofibromas

\begin{tabular}{lccc}
\hline \multicolumn{1}{c}{ Gene expressed } & $\begin{array}{c}\text { Schwann } \\
\text { cell }\end{array}$ & $\begin{array}{c}\text { Perineurial } \\
\text { cell }\end{array}$ & Fibroblast \\
\hline Pro $\alpha$ 1(I) collagen & + & + & + \\
Pro $\alpha$ 1(IV) collagen & + & + & $-*$ \\
Pro $\alpha 2$ (VI) collagen & $+^{*}$ & + & + \\
Laminin B1 chain & + & + & + \\
Laminin A chain & $-*$ & + & $-*$ \\
Fibronectin & $-*$ & + & + \\
\end{tabular}

Data are based on Northern and in situ hybridizations, as presented in Results.

* Not detectable by in situ hybridization.

${ }^{\ddagger}$ In situ and Northern hybridizations suggest abundant steady-state levels of the corresponding mRNA.
Figure 3. Northern transfer analysis. (A) RNA, $10 \mu \mathrm{g}$ per lane, isolated from (a) third passage of cultured human skin fibroblasts; $(b)$ neurofibroma primary culture; and $(c)$ third passage of subculture of cells from the same tumor as in lane $b$. The same filter with intermittent washes was sequentially hybridized with cDNAs for $\alpha_{1}(\mathrm{I}), \alpha_{2}(\mathrm{I}), \alpha_{1}(\mathrm{VI}), \alpha_{2}(\mathrm{VI})$, and $\alpha_{3}(\mathrm{VI})$ procollagen chains, fibronectin $(F N)$, and laminin $(L A M)$ B2 chain, as indicated in the figure. $(B)$ Hybridization with CDNAs for $\alpha_{1}$ (III) and $\alpha_{1}$ (IV) procollagen chains, elastin (EL), and laminin ( $\left.L A M\right)$ A chain in four different filters containing RNA in lanes $a, b$, and $c$ from the same cell sources as in $A$. The positions of 10-kb laminin A chain, 8.5-kb $\alpha_{3}(\mathrm{VI}), 6.8-\mathrm{kb} \alpha_{1}(\mathrm{IV}), 4.8-\mathrm{kb} \alpha_{1}(\mathrm{III})$, and $3.5-\mathrm{kb}$ elastin or $\alpha_{2}(\mathrm{VI})$ chain mRNAs are indicated with arrows.

in expressing the type VI collagen genes (Fig. 5), while expressing the fibronectin gene at a very low level (Fig. 7). Also, in some cases the RNA preparations from passaged cells appeared to be enriched in mRNA for pro $\alpha_{1}$ (IV) collagen and laminin A chain sequences (Fig. 3). These observations can be explained by relative enrichment of the cultures with perineurial cells, since fibroblasts, the other major cell type in these cultures, do not express type IV collagen genes at significant levels (Fig. 6).

\section{Discussion}

Previous biochemical and immunocytochemical studies have revealed that the abundant extracellular matrix of neurofibromas contains collagen types I, III, IV, V, and VI, as well as noncollagenous glycoproteins, fibronectin, laminin, and nidogen (5-14). The cell populations within neurofibromas consist mainly of nerve-derived cells: Schwann cells, perineurial cells, and fibroblasts (5). In addition, the presence of mast cells, $\alpha_{1}$-antitrypsin-positive phagocytic cells, as well as cells with endothelial, epithelial, or muscle cell differentiation have been demonstrated in localized areas (5). Considering the relative amounts and the biosynthetic repertoire of the cells present in neurofibromas, it appeared reasonable to postulate that Schwann cells, perineurial cells, and/or fibroblastic cells are primarily responsible for the synthesis of extracellular matrix components in neurofibromas. However, no direct evidence for the specific assignment of these three different cell types with respect to expression of matrix genes has been presented previously. 

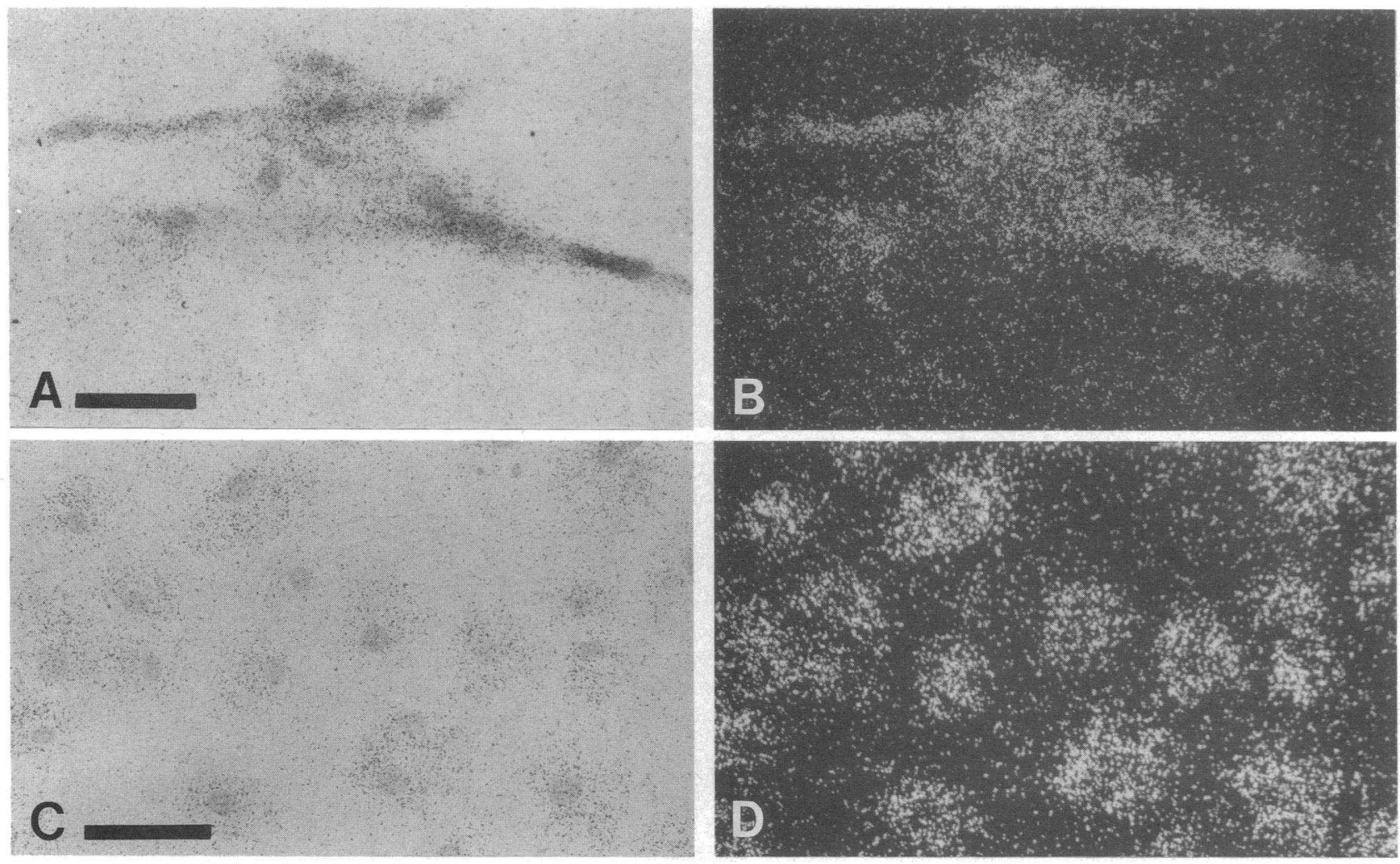

Figure 4. In situ hybridization of $(A$ and $B)$ Schwann cells in a primary culture and $(C$ and $D)$ perineurial cells in the third passage culture with a cDNA corresponding to $\alpha_{1}(\mathrm{I})$ procollagen chain. $\left.{ }^{35} \mathrm{~S}\right] \mathrm{cDNA}-\mathrm{mRNA}$ hybrids are visualized using $(A$ and $C)$ brightfield and $(B$ and $D)$ darkfield optics. Bars, $100 \mu \mathrm{m}$.

In this study, we have analyzed the connective tissue biosynthetic profile of Schwann cells, perineurial cells, and fibroblasts, both in mixed primary and in passaged cell cultures. A combination of morphologic and immunocytochemical criteria allowed the identification of individual cells to be representative of each of three different cell types $(15,16)$.

Northern hybridizations revealed the presence of mRNA transcripts for subunits of collagen types I, III, IV, and VI, as well as those for fibronectin, laminin, and elastin, indicating that at least one of the cell types present in the initial outgrowth expressed the corresponding genes. Precise assignment to individual cell types was achieved by in situ hybridizations, which revealed a differential profile of matrix gene expression. All three cell types expressed the pro $\alpha_{1}(\mathrm{I})$ collagen gene, consistent with a previous demonstration that type I procollagen mRNA levels are predominant in neurofibroma tissues (12).

Of interest was the observation that the size of $\alpha_{3}(\mathrm{VI})$ collagen mRNA transcripts in primary neurofibroma cell cultures was somewhat smaller than those noted in skin fibroblast cultures (Fig. $3 A$ ). We have previously shown that $\alpha_{3}(\mathrm{VI})$ collagen transcripts are quite heterogeneous in size, and at least four discrete mRNAs ranging from 8.3 to $9.2 \mathrm{~kb}$ have been detected in fetal skin fibroblasts (26). The nature of these multiple mRNA species is currently unclear and the difference in size
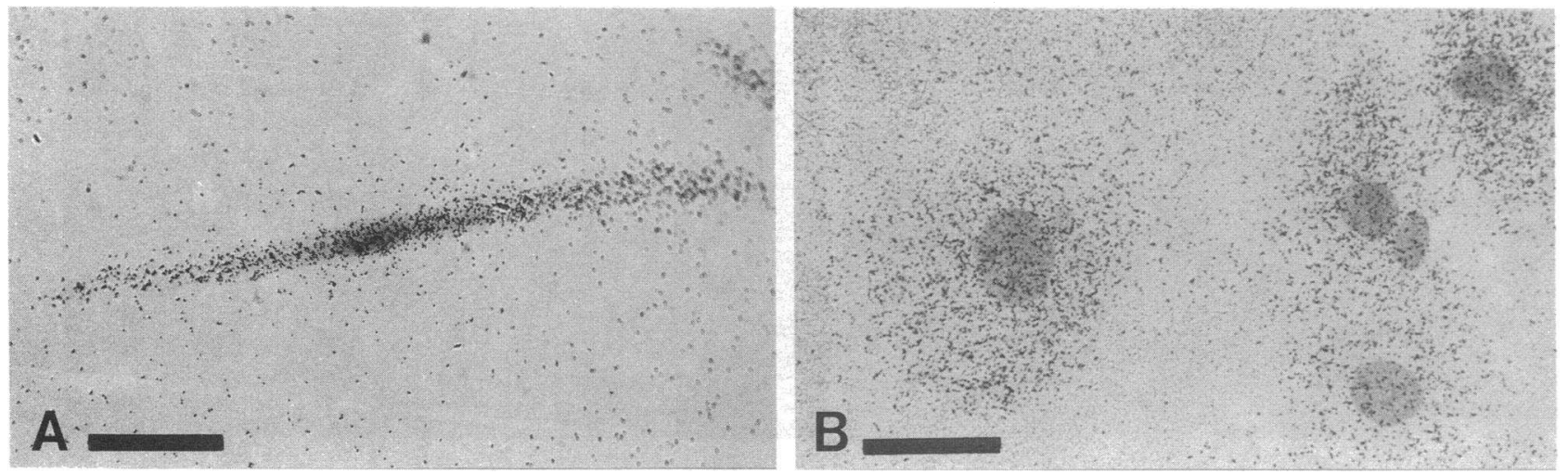

Figure 5. In situ hybridization of $(A)$ Schwann cells and $(B)$ perineurial cells in a primary culture with a cDNA for $\alpha_{2}(\mathrm{VI})$ procollagen chain. Bars, $100 \mu \mathrm{m}$. 

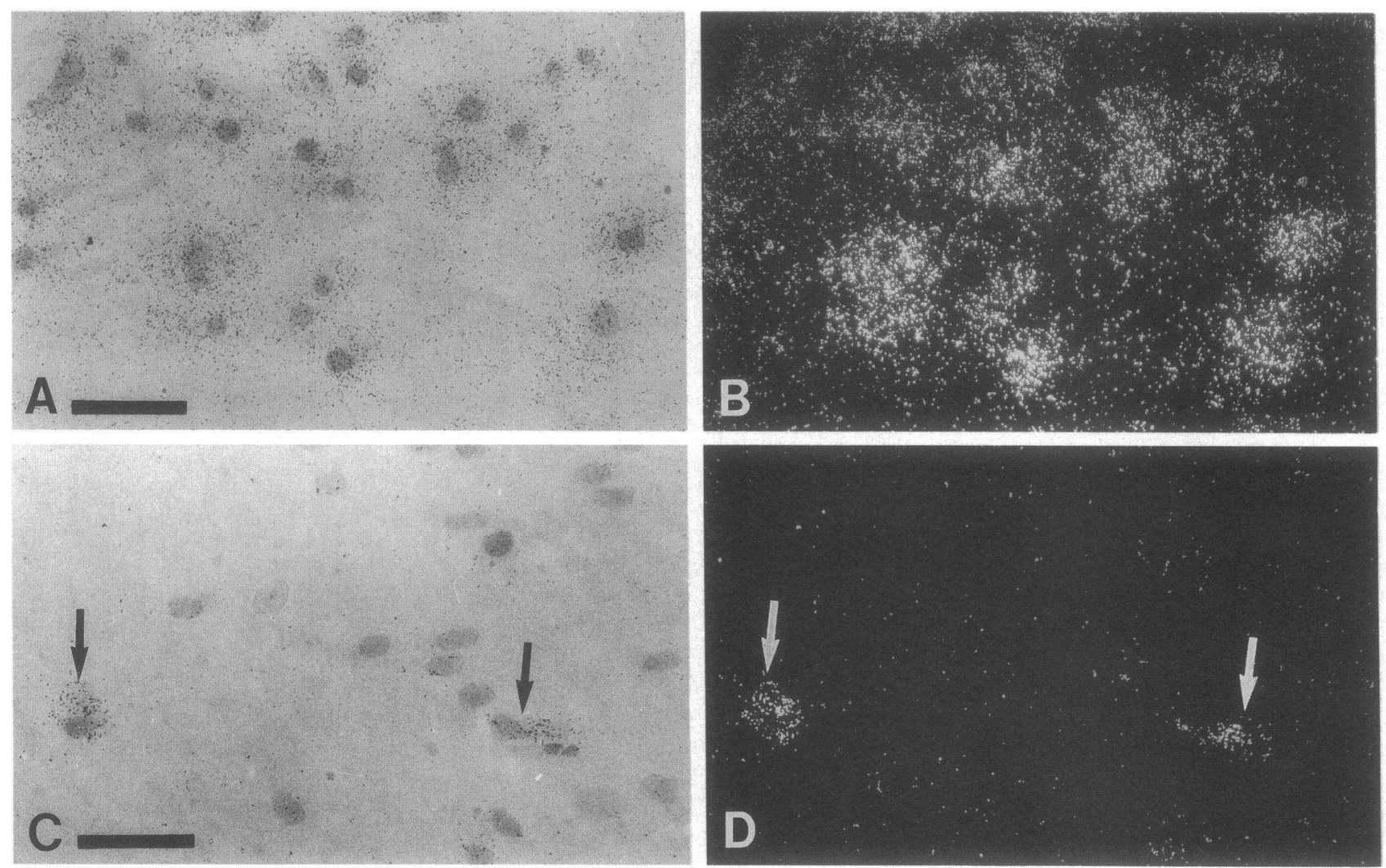

Figure 6. In situ hybridization with a cDNA for $\alpha_{1}$ (IV) procollagen chain. ( $A$ and $B$ ) Mixed primary Schwann and perineurial cell culture. ( $C$ and $D$ ) Culture area with a predominant fibroblast outgrowth. Only two Schwann cells, containing $\alpha_{1}(\mathrm{IV})$ collagen mRNA, can be seen (arrows). $(A$ and $C)$ Brightfield optics; $(B$ and $D)$ darkfield optics. Bars, $100 \mu \mathrm{m}$.

may reside either in the coding or noncoding region of the transcript. It is possible that the smaller transcript is preferentially expressed in one of the nerve-derived cell types. The easy detectability of type VI collagen mRNA transcripts suggests that this particular genetically distinct collagen type may be an abundant gene product of neurofibroma cells. This observation is also consistent with recent findings that type VI collagen represents a major fraction of collagen in a variety of connective tissues (33). Furthermore, human skin fibroblasts actively express type VI procollagen genes both in culture and in normal human skin, as demonstrated by quantitative slot- blot and in situ hybridizations, suggesting that the observations in cell culture reflect the in vivo situation in relevant tissue (34). Based on these findings, one could suggest that type VI collagen may also be a predominant matrix component in neurofibromas, but direct quantitation is still lacking.

Examination of pro $\alpha_{1}$ (IV) collagen gene expression by in situ hybridizations revealed that Schwann cells and perineurial cells contained mRNA transcripts for this collagen chain, whereas fibroblasts were essentially negative in this assay. It has been previously shown that cultured rat nerve Schwann cells synthesize type IV collagen protein, but the expression of
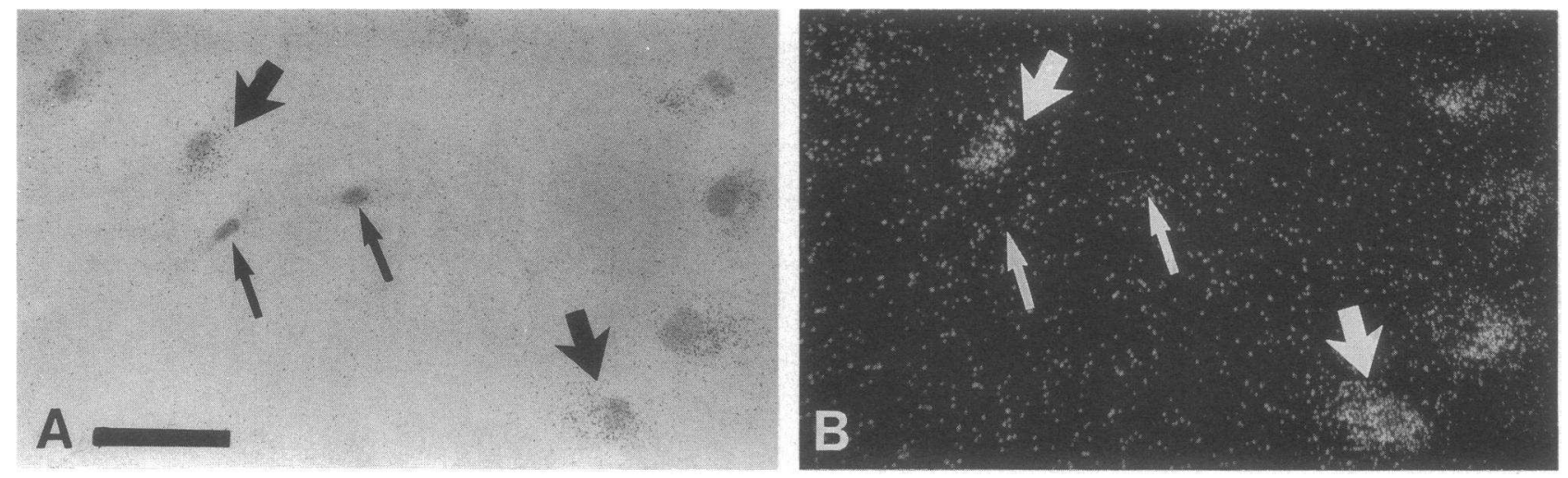

Figure 7. In situ hybridization of a primary neurofibroma cell culture with a cDNA for fibronectin. Fibroblasts and perineurial cells express the fibronectin gene (large arrows), whereas Schwann cells are essentially devoid of fibronectin mRNA (small arrows). $(A)$ Brightfield optics; $(B)$ darkfield optics. Bar, $100 \mu \mathrm{m}$. 
Figure 8. In situ hybridization of a third passage neurofibroma cell culture with a cDNA for laminin A chain. ${ }^{35}$ S]cDNA-mRNA hybrids are detected only in cultures enriched in perineurial cells. $(A)$ Brightfield optics; $(B)$ darkfield optics. Bar, $100 \mu \mathrm{m}$.

this gene requires the axonal contact (35). This observation together with the results of the present study suggest that Schwann cells derived from neurofibromas may be more autonomous and express the type IV collagen genes in mixed cell culture without axonal contact. Previous studies have demonstrated low but clearly detectable levels of type IV procollagen mRNAs in human skin fibroblast cultures (34). It is unclear, therefore, whether the neurofibroma fibroblasts do express the pro $\alpha_{1}$ (IV) collagen gene at all, or whether the level is too low for detection by in situ hybridization. Most important, however, is our demonstration that perineurial cells are active in expressing the $\alpha_{1}$ (IV) collagen gene. In normal nerves, perineurial cells are surrounded by a thick basement membrane, presumably containing type IV collagen, together with other basement membrane zone components $(36,37)$. Rat perineurial cells have also been shown to express the $\alpha_{1}$ (IV) collagen gene in vitro and in vivo (16). The present observations suggest that neurofibroma perineurial cells share common characteristics with normal perineurial cells. These results also relate to immunocytochemical demonstration that type IV collagen is evenly distributed in the matrix of neurofibromas $(5,6,8)$. Thus, the perineurial cell appears to play a significant role in contributing to the deposition of the extracellular matrix in neurofibromas.

In addition to collagenous proteins, the expression of genes for noncollagenous glycoproteins of the basement membrane zone, laminin and fibronectin, was examined. Expression of the laminin B1 chain gene was clearly detectable by in situ hybridization on Schwann cells, perineurial cells and fibroblasts. These observations are consistent with previous demonstration that Schwann cells, with or without axonal contact, synthesize laminin (38). Human skin fibroblasts have been shown to express the genes encoding laminin A, B1, and B2 chains (28). However, the mRNA levels for these three different laminin polypeptides have been shown to deviate from the 1:1:1 stoichiometry, expected on the basis of proposed molecular model of the laminin protein $(28,39)$. Specifically, laminin A chain mRNA levels were considerably lower, or undetectable, as compared with those for the B chain mRNAs (28). This observation is consistent with our finding here that laminin A chain specific mRNAs could be detected only in cell cultures established from three out of seven neurofibromas. Previous studies examining normal rat Schwann cells (38) or rat RN22 schwannoma cells $(40,41)$ have failed to detect a full-length laminin A chain with an apparent $M_{\mathrm{r}} \sim 440 \mathrm{kD}$. These observations have led to the suggestion that Schwann cells may synthesize an A chainlike shortened polypeptide, with the laminin molecule having configuration distinct from the normal cross-shaped appearance of laminin isolated from mouse EHS sarcoma $(39,40)$.

Fibronectin gene expression was clearly detectable in perineurial cells and fibroblasts. Schwann cells, on the other hand, either did not express this gene or expressed it at a very low level under cell culture conditions of the present study. This observation is consistent with previous studies indicating that normal rat Schwann cells do not synthesize fibronectin (42, 43). On the other hand, rat RN22 schwannoma cells clearly synthesize fibronectin (41), indicating that the latter cells have a different culture phenotype from the Schwann cells derived from normal nerves or from neurofibromas.

Of interest was the demonstration that neurofibroma cell cultures expressed the elastin gene. This observation is consistent with recent reports indicating that human skin fibroblasts contain elastin-specific mRNAs $(29,44)$. Histopathologic, ultrastructural, and biochemical analyses have shown that cutaneous neurofibromas contain low amounts of elastin $(12,45)$, and in a normal nerve elastic fibers are present only in epi- and perineurium whereas endoneurium is devoid of this protein (36). Thus, it appears that fibroblasts and perineurial cells are the principal cell types containing the elastin mRNAs in cultures studied here.

In summary, the observations utilizing in situ hybridizations with human sequence specific cDNAs indicate differential gene expression profiles by the three major cell types, viz. Schwann cells, perineurial cells, and fibroblasts, in neurofibromas. It is conceivable that all three cell types contribute to the development of the extracellular matrix of neurofibromas, yet each cell type may synthesize a different set of matrix molecules. Factors leading to activation of the gene expression in these three different cell types are currently unknown. However, a recent demonstration that neurofibromas contain an abundance of plasma-derived fibronectin has allowed us to suggest that these cells are accessible also to other plasma proteins, including a variety of growth factors, such as epidermal growth factor and nerve growth factor (5). It is conceivable that these affector molecules may modulate the extracellular matrix production by Schwann cells, perineurial cells and fibroblasts in a differential manner, thus partly explaining the vari- 
ability in the biosynthetic repertoire of these neurofibroma cells.

\section{Acknowledgments}

The authors wish to thank Kathryn Gay for expert technical assistance. Skillful secretarial help was provided by Eileen O'Shaughnessy. The authors thank Dr. Taina Pihlajaniemi and Dr. Darwin Prockop for the $\alpha_{1}(\mathrm{IV})$ collagen cDNA, and Dr. Michael Fazio for human elastin cDNA. Dr. Mark Lebwohl (Mt. Sinai School of Medicine) and Dr. Gary Lask (Thomas Jefferson University Hospital) provided some of the tumors.

This study was supported in part by the U. S. Public Health Service, National Institutes of Health grants AR-28450, GM-28833, AR-35297, AR-38188, AR-38912, AR-38923, and T32 AR-7561, and by the Finnish Cultural Fund and the Finnish Academy of Sciences. Dr. Peltonen is a recipient of a Young Investigator Award from National Neurofibromatosis Foundation.

\section{References}

1. Crowe, F. W., W. J. Schull, and J. V. Neel. 1956. A Clinical, Pathological and Genetic Study of Multiple Neurofibromatoses. Charles C. Thomas, Springfield, IL.

2. Barker, D., E. Wright, K. Nguyen, L. Cannon, P. Fain, D. Goldgar, D. T. Bishop, J. Carey, B. Baty, J. Kivlin, H. Willard, J. S. Waye, G. Gregi, L. Leinwand, Y. Nakamura, P. O'Connel, M. Leppert, J-M Lalouel, R. White, and M. Skolnik. 1987. Gene for von Recklinghausen's neurofibromatosis is in the pericentromeric region of chromosome 17. Science (Wash. DC). 236:1100-1102.

3. Seizinger, B. R., G. A. Rouleau, L. J. Ozelius, A. H. Lane, A. G. Faryniarz, M. V. Chao, S. Huson, B. R. Korf, D. M. Parry, M. A. Pericak-Vance, F. S. Collins, W. J. Hobbs, B. G. Falcone, J. A. Iannazzi, J. C. Roy, P. H. St. George-Hyslop, R. E. Tanzi, M. A. Bothwell, M. Upadhyaya, P. Harper, A. E. Goldstein, D. L. Hoover, J. L. Bader, M. A. Spence, J. J. Mulvihill, A. S. Aylsworth, J. M. Vance, G. O. D. Rossenwasser, P. C. Gaskell, A. G. Roses, R. L. Martuza, X. O. Breakfield, and J. F. Gusella. 1987. Genetic linkage of von Recklinghausen's neurofibromatosis to the nerve growth factor receptor gene. Cell. 49:589-594.

4. Riccardi, V. M. 1981. Von Recklinghausen's neurofibromatosis. N. Engl. J. Med. 305:1617-1627.

5. Peltonen, J., S. Jaakkola, M. Lebwohl, S. Renvall, L. Risteli, I. Virtanen, and J. Uitto. 1988. Cellular differentiation and expression of matrix genes in type 1 neurofibromatosis. Lab. Invest. 59:760-771.

6. Peltonen, J., R. Penttinen, H. Larjava, and H. Aho. 1986. Collagens in neurofibromas and neurofibroma cell cultures. Ann. NY Acad. Sci. 486:260-270.

7. Peltonen, J., H. Aho, T. Halme, K. Näntö-Salonen, M. Lehto, J.-M. Foidart, V. Duance, A. Vaheri, and R. Penttinen. 1984. Distribution of different collagen types and fibronectin in neurofibromatosis tumors. Acta Pathol. Microbiol. Immunol. Scand. Sect. A Pathol. 92:345-352.

8. Peltonen, J., J.-M. Foidart, and H. J. Aho. 1984. Type IV and V collagens in von Recklinghausen's neurofibromas: an immunohistochemical and electrophoretical study. Virchows Arch. Cell Pathol. 47:291-301.

9. Gay, R. E., S. Gay, and R. E. Jones. 1983. Histological and immunohistological identification of collagens in basement membranes of Schwann cells of neurofibromas. Am. J. Dermatopathol. 5:317-325.

10. Fleischmajer, R., R. Timpl, M. Dziadek, and M. Lebwohl. 1985. Basement membrane proteins, interstitial collagens, and fibronectin in neurofibroma. J. Invest. Dermatol. 85:54-59.

11. Engel, J., H. Furthmayr, E. Odermatt, H. Von der Mark, M. Aumailley, R. Fleischmajer, and R. Timpl. 1985. Structure and macromolecular organization of type VI collagen. Ann. NY Acad. Sci. 460:25-37.
12. Uitto, J., L. Matsuoka, M.-L. Chu, T. Pihlajaniemi, and D. J. Prockop. 1986. Connective tissue biochemistry of neurofibromas. Ann. NY Acad. Sci. 486:271-286.

13. Miettinen, M., J.-M. Foidart, and P. Ekblom. 1983. Immunohistochemical demonstration of laminin, the major glycoprotein of basement membranes, as an aid in the diagnosis of soft tissue tumors. Am. J. Clin. Pathol. 79:306-311.

14. Dziadek, M., D. Edgar, M. Paulsson, R. Timpl, and R. Fleischmajer. 1986. Basement membrane proteins produced by Schwann cells and in neurofibromatosis. Ann. NY Acad. Sci. 460:248-259.

15. Peltonen, J., S. Jaakkola, I. Virtanen, and L. Pelliniemi. 1987. Perineurial cells in culture: an immunocytochemical and electron microscopic study. Lab. Invest. 57:480-488.

16. Jaakkola, S., J. Peltonen, and J. Uitto. 1989. Perineurial cells co-express genes encoding interstitial collagens and basement membrane zone components. J. Cell Biol. 108:1157-1163.

17. Chomczynski, P., and N. Sacchi. 1987. Single-step method of RNA isolation by acid guanidinium thiocyanate-phenol-chloroform extraction. Anal. Biochem. 162:156-159.

18. Thomas, P. S. 1980. Hybridization of denatured RNA and small DNA fragments transferred to nitrocellulose. Proc. Natl. Acad. Sci. USA. 69:1408-1412.

19. Maniatis, T., E. F. Fritsch, and J. Sambrook. 1982. Molecular Cloning. Cold Spring Harbor Laboratories, Cold Spring Harbor, NY. 109.

20. Brahic, M., and A. T. Haase. 1978. Detection of viral sequences of low reiteration frequency by in situ hybridization. Proc. Natl. Acad. Sci. USA. 75:6125-6129.

21. Peltonen, J., S. Jaakkola, K. Gay, D. R. Olsen, M.-L. Chu, and J. Uitto. 1989. Expression of extracellular matrix genes by cultured human cells: localization of messenger RNAs and antigenic epitopes. Anal. Biochem. 178:184-193.

22. Chu, M.-L., J. C. Myers, M. P. Bernard, J.-F. Ding, and F. Ramirez. 1982. Cloning and characterization of five overlapping cDNAs specific for the human pro $\alpha 1$ (I) collagen chain. Nucleic Acids Res. 10:5925-5934.

23. Kuivaniemi, H., G. Tromp, M.-L. Chu, and D. J. Prockop. 1988. Structure of a full-length cDNA clone for the preproa2(I) chain of human type I procollagen. Biochem. J. 252:633-640.

24. Chu, M.-L., D. Weil, W. deWet, M. Bernard, M. Sippola, and R. Ramirez. 1985. Isolation of cDNA and genomic clones encoding human pro $\alpha$ 1(III) collagen: partial characterization of the 3'-end region of the gene. J. Biol. Chem. 260:4357-4363.

25. Pihlajaniemi, T., K. Tryggvason, J. C. Myers, M. Kurkinen, R. Lebo, M. C. Cheung, D. J. Prockop, and C. D. Boyd. 1986. cDNA clones coding for the pro- $\alpha$ l(IV) chain of human type IV procollagen reveal an unusual homology of amino acid sequences in two halves of the carboxyl-terminal domain. J. Biol. Chem. 260:7681-7687.

26. Chu, M.-L., K. Mann, R. Deutzmann, D. Pribula-Conway, C. C. Hsu-Chen, M. P. Bernard, and R. Timpl. 1987. Characterization of three constituent chains of collagen type VI by peptide sequences and cDNA clones. Eur. J. Biochem. 168:309-317.

27. Bernard, M. P., M. Kolbe, D. Weil, and M.-L. Chu. 1985. Human cellular fibronectin: comparison of the carboxyl-terminal portion with rat identifies primary structural domains separated by hypervariable regions. Biochemistry. 24:2698-2704.

28. Olsen, D., T. Nagayoshi, M. Fazio, J. Peltonen, S. Jaakkola, D. Sanborn, T. Sasaki, H. Kuivaniemi, M.-L. Chu, R. Deutzmann, R. Timpl, and J. Uitto. 1989. Human laminin: cloning and sequence analysis of cDNAs encoding A, B1 and B2 chains, and expression of the corresponding genes in human skin and cultured cells. Lab. Invest. In press.

29. Fazio, M. J., D. R. Olsen, H. Kuivaniemi, M.-L. Chu, J. M. Davidson, J. Rosenbloom, and J. Uitto. 1988. Isolation and characterization of human elastin cDNAs and age-associated variation in elastin gene expression in cultured human skin fibroblasts. Lab. Invest. 58:270-277.

30. Krone, W., G. Jirikowski, D. Mühleck, H. Kling, and H. Gall. 
1983. Cell culture studies on neurofibromatosis (von Recklinghausen). II. Occurrence of glial cells in primary cultures of peripheral neurofibromas. Hum. Genet. 63:247-251.

31. Mukai, K., J. Rosai, and W. H. C. Burgdorf. 1980. Localization of factor VIII-related antigen in vascular endothelial cells using an immunoperoxidase method. Am. J. Surg. Pathol. 4:273-276.

32. Virtanen, I., V.-P. Lehto, E. Lehtonen, T. Vartio, S. Stenman, P. Kurki, O. Wager, J. V. Small, and R. A. Badley. 1981. Expression of intermediate filaments in cultured cells. J. Cell Sci. 50:45-64.

33. Trüeb, B., T. Schreier, P. Bruckner, and K. H. Winterhalter. 1987. Type VI collagen represents a major fraction of connective tissue collagens. Eur. J. Biochem. 166:699-703.

34. Olsen, D., J. Peltonen, S. Jaakkola, M.-L. Chu, and J. Uitto. 1989. Collagen gene expression by human skin fibroblasts: abundant steady-state levels of type VI procollagen mRNAs. J. Clin. Invest. 83:791-795.

35. Bunge, M. B., and R. P. Bunge. 1986. Linkage between Schwann cell extracellular matrix production and ensheathment function. Ann. NY Acad. Sci. 486:241-247.

36. Thomas, P. K. 1963. The connective tissue of peripheral nerve: an electron microscope study. J. Anat. 97:35-44.

37. Timpl, R., H. Wiedemann, V. Van Delden, H. Furthmayr, and K. Kühn. 1981. A network model for the organization of type IV collagen molecules in basement membranes. Eur. J. Biochem. 120:203-211.

38. Cornbrooks, C. J., D. J. Carey, J. A. McDonald, R. Timpl, and
R. P. Bunge. 1983. In vivo and in vitro observations on laminin production by Schwann cells. Proc. Natl. Acad. Sci. USA. 80:3850-3854.

39. Martin, G. R., and R. Timpl. 1987. Laminin and other basement membrane components. Annu. Rev. Cell Biol. 3:57-85.

40. Edgar, D., R. Timpl, and H. Thoenen. 1988. Structural requirements for the stimulation of neurite outgrowth by two variants of laminin and their inhibition by antibodies. J. Cell Biol. 106:12991306.

41. Palm, S., and L. Furcht. 1983. Production of laminin and fibronectin by schwannoma cells: cell-protein interactions in vitro and protein localization in peripheral nerve in vivo. J. Cell Biol. 96:12181226.

42. Fields, K. L. 1980. The study of Schwann cells using antigenic markers. Trends Neurosci. 3:236-238.

43. Fields, K. L., J. P. Brockes, R. Mirsky, and L. B. M. Wendon. 1978. Cell surface markers for distinguishing different types of rat dorsal root ganglion cells in culture. Cell. 14:43-51.

44. Giro, M. G., A. I. Oikarinen, H. Oikarinen, G. C. Sephel, J. Uitto, and J. M. Davidson. 1985. Demonstration of elastin gene expression in human skin fibroblast cultures and reduced tropoelastin production by cells from a patient with atrophoderma. J. Clin. Invest. 75:672-678.

45. Peltonen, J. 1985. Connective Tissue in von Recklinghausen's Neurofibromatosis. Ph.D. Thesis. University of Turku, Turku, Finland. 